\title{
EFFECT OF PRE-SOWING TREATMENTS ON SEED GERMINATION AND SEEDLING EMERGENCE OF Celtis tournefortii LAM. - KURDISTAN REGION OF IRAQ
}

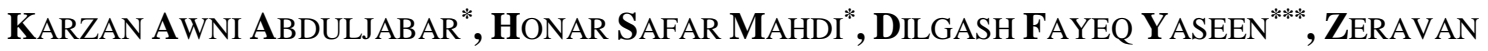 \\ MERGYE ${ }^{* * * *}$, SAMI YOUSEEF $^{* \&^{* * * * * * * *}}$ \\ *Dept. of Horticulture, Akre Technical College, Duhok Polytechnic University. Kurdistan Region-Iraq \\ ** Dept. of Recreation and Ecotourism, College of Agricultural Engineering Sciences, University of Duhok, \\ Kurdistan Region-Iraq \\ *** Dept. of Forestry, College of Agricultural Engineering Sciences, University of Duhok, Kurdistan Region-Iraq \\ **** Agriculture Directorate, Ministry of Agriculture, Kurdistan Region-Iraq. \\ *****\&* AMAP (botany and Modelling of Plant Architecture and vegetation), University of Montpellier / CIRAD \\ / CNRS / INRA / IRD - AMAP, CIRAD TA A51/PS2, 34398 Montpellier Cedex 5, France.
}

(Received: July 31, 2019; Accepted for Publication: September 5, 2019)

\begin{abstract}
The seed germination and regeneration ecology of tree seeds are different because of the process of evolution and the influence of some environmental factors. Thus, determining factors of the germination rate and seedling emergence timing are understandable. The main purpose this article is to investigate the impact of the pre-sowing treatments on the germination and seedling emergence timing of Celtis tournefortii, the native tree species in the Kurdistan region. The study pretreatment include untreated seeds (control), fruit seed with exocarp, chemical scarification 5, 10 and 15 minutes, mechanical scarification, hot water soaking for 5, 10 and 15 minutes, cold stratification for 1, 2 and 3 months, Gibberellic acid with concentrations of 500,1000 and $2000 \mathrm{ppm}$ for five minutes soaking, and water soaking for 1,2 and 3 days. The result revealed that the best germination of seeds $46 \%$ was achieved from Stratification for 3 months, Mechanical scarification, and seed treated with concentration 500ppm of gibberellic acid). While there some treatments are reducing the seed germination of this tree species which were 10 and 15minutes in $\mathrm{H}_{2} \mathrm{SO}_{4}$, normal water 1 and 2 days, and soaking in Hot water for 10 and 15minutes. Moreover, the result showed that the seedling emergence are related to the seed sowing date where the suitable sowing date for this species was in winter and early spring season. This finding has important implication, particularly for the managers of the plant nurseries, for developing a timetable for the suitable sowing time of the tree species seeds. Therefore, the study results could be used as a base for investigation and for future studies in seed germination of Celtis tourneforti as well as to maximize the germination success rate.
\end{abstract}

KEYWORDS: Celtis tournefortii, scarification, Normal and Hot water, Exocarp, Stratification, seedling emergence, Seed germination

https://doi.org/10.26682/ajuod.2019.22.2.13

\section{INTRODUCTION}

$\mathbf{T}$ The Nettles-Trees or Hackberries are deciduous trees which belong to Celtis genus (See Townsend 1980; Shahbaz 2010). This kind of trees are often fast-growing belong to Celtidaceae which angiosperm species, previously was a part of (Ullmaceae Celtidaceae) (Judd et al. 1994; Song et al. 2001). This group of tree species consists of $100-150$ species which is distribute widely in the northern hemisphere and southern Africa such as (savannah areas, temperate regions and rain forest) (Todzia 1989; Ulloa 1995). Moreover, the mostly tree genus Celtis are found in temperate regions (Southern Europe, Mediterranean Region, North America, South America, Asia, and Africa) (Todzia 1989; Ulloa 1995). The subgenus of these trees is called Euceltis. All these species are similar to each other but they are mainly differentiate between them by the characteristic of their leaf (e.g. texture, size, marginal serration degree and veining pattern) and their drupes (size and color of drupes; e.g. stone of drupe is smooth or reticulate). These trees species are capable to 
survive in harsh environment, i.e. hot dry and grow in stress sites, where many other deciduous trees are not capable to grow in such locations (Sheat, 1948). According to Flora of Iraq (Townsend, 1980),there are two Celtis tree species native to the Kurdistan region (North of Iraq). They are: Celtis australis L. (The European Nettles-Trees are native to the Mediterranean circumstance (Shahbaz 2010; Tison et al. 2014) and Celtis tournefortii Lam. (The Oriental Hackberries, is native to the eastern Mediterranean, throughout the IranoAnatolian Region, to Caucasus Region (Townsend 1980; Shahbaz 2010). Knowing that the Kurdistan Region areas, belongs to the IranoAnatolian hotspot for biodiversity (Youssef et al. 2015, 2017, 2019) where these Celtis species are locally founded such as in the lower mountains and valleys of Gara, Avroman, Sinjar, Bekhair (Townsend 1980; Shahbaz 2010).

In the context of economic botany, Celtis tree species have great value for the activities of human livelihood. Recently, there are a large number of literatures on the economic value of Celtis species, especially for their edible fruits, and antioxidants characteristics (Y1ldırım, et al, 2017). Furthermore, their durable and elastic wood is commonly used to make pulley, chopstick, spoon, cane, shovel, various tools and buildings such as agricultural tools and construction of the carving, wood is used in the making paper. They are preferred as ornamental plants in the parks and gardens of urban areas, they can be used as live fences in the enclosure and confinement of facilities such as parks, gardens, public, cemeteries, fields and nurseries and their succulent fruits are consumed with pleasure by various animals, especially bird species. (Kayac1k, 1981; Demir et al., 2002; Doygun \& Ok, 2006; Sattarian, 2006; Gültekin, 2007). Tree's Fruit, leaves, and gum use as a medicine and use it for cosmetics in recent years due to the increasing interest in fragrances (Chevallier, 1996; Tardio et al., 2006).

According to previous studies, it's often difficult to propagate Celtis tree species sexually, due to the hard coat of the seeds (Ellis, et al., 1985; Demir et al., 2002; Guney et al., 2008). In a study Yücedağ and Gültekin (2008) on germination of Celtis australis and $C$. tournefortii seeds, it was found that sowing times and folding had a significant effect on germination rates. In the study of Yücedağ \&
Gültekin (2008), it is stated that a period between 30-90 days are suitable for the coldwet folding period and November, December and January are recommended for an appropriate sowing time. Guney et al., (2008) highlighted that the germination percentages of Celtis species were high when the seeds were pretreated by 60 and 90 days of cold stratification. Similarly, cold stratifying seeds for 2 - 3 months recommended by Sheat(1948), Griffiths and Huxley (1992). To increase the seed germination rate the study of Acar and Ercisli (2017) has used normal water and cold stratification to breakdown the seed hard coat. The growing environment conditions could also effect on the germination rate of the seeds (Singh et al. 2004), as well as the characteristics of heritability, and the age of tree. Therefore, the main aim of this experimental study is to conduct a scientific investigation on the effect of some pre-sowing treatments on the germination rate and seedling emergence timing of $C$. tournefortii in Kurdistan Region of Iraq.

\section{MATERIALS AND METHODS:}

\subsection{Experiment site}

The study was carried out at the field nursery of Lemon Tree Trust organization (LTT CIC: https://lemontreetrust.org) at Domiz1 Syrian Refugee camp - Duhok governorate (Latitude: $\left.36^{\circ} 78^{\prime} 29 \mathrm{~N}\right)$ and (Longitude: 42 $88^{\prime} 61 \mathrm{E}$ ) elevation $(425 \mathrm{~m})$ (Figure 1). The nursery area is located in the upper of Mesopotamian plain between Duhok and Mosul cities (around $15 \mathrm{~km}$ far from Duhok city center and $54 \mathrm{~km}$ from Mosul city). From landscape standpoint, this Mesopotamian plain is mainly flat (altitude ranging from 200 to 500 masl) In addition, the mean of temperature for 2018 - 2019 was $\left(26^{\circ} \mathrm{C}\right)$ and precipitation $(995 \mathrm{~mm})$ which started on October-November and end by the end of April-May (Youssef et al. 2017, 2018, 2019). 


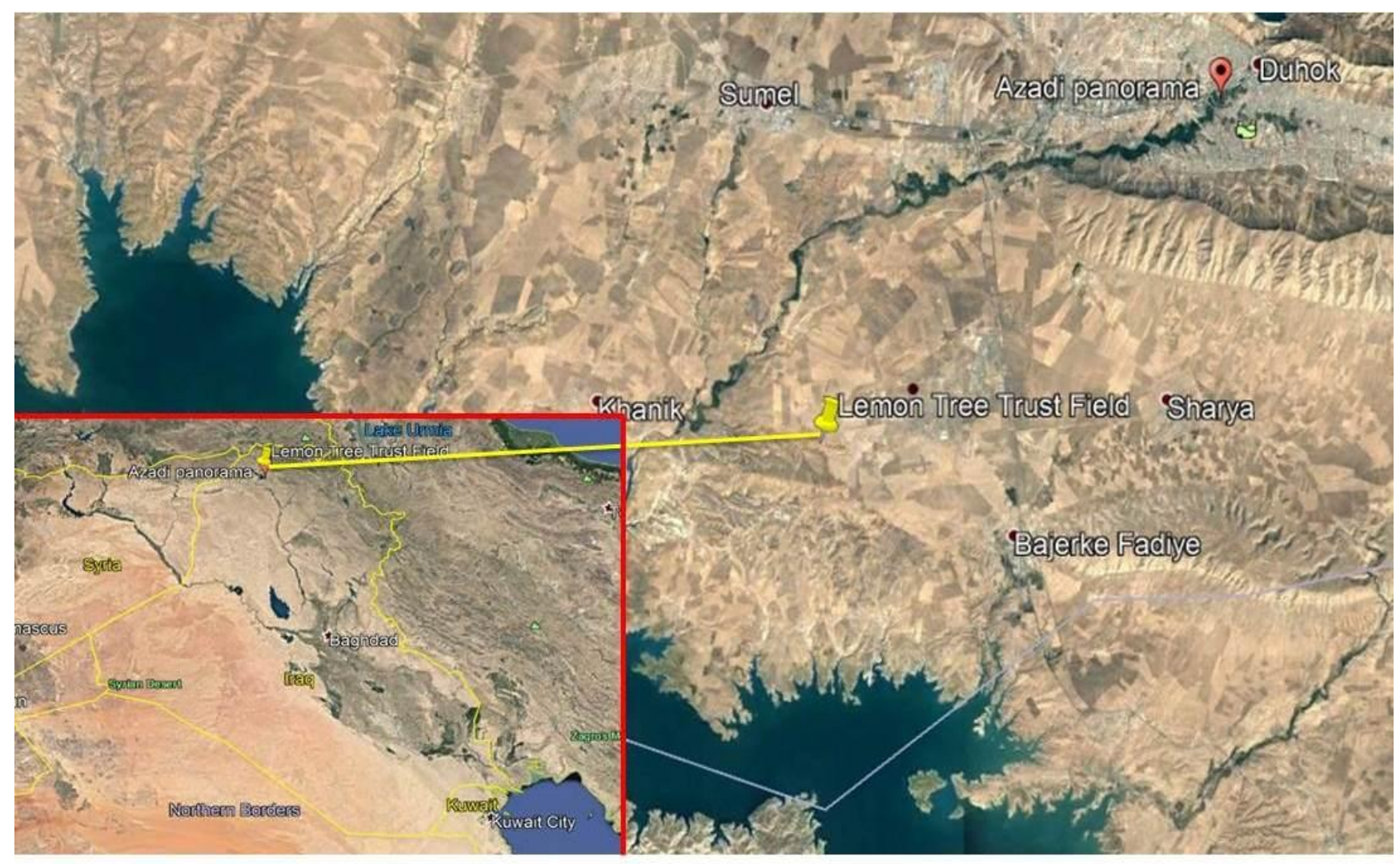

Figure 1: Location of Lemon Tree Trust Field at Domiz1 Syrian Refugee camp.

\subsection{Fruit Collection and Seed Treatments :}

The Celtis tournefortii fruits were collected in October, 2018 from Gara Mountain (Latitude: $\left.37^{\circ} 00^{\prime} 49.55\right)$ and (Longitude: $43^{\circ} 21^{\prime} 13.01$ ) elevation $(2748 \mathrm{~m})$, then coat of these fruits have been removed by scratching it on the concrete ground, thus the study obtained the seeds without flesh coat. In this study, several presowing treatment have been tested in order to obtain the best treatment in the term of maximizing the germination rate. The study treatments were:

Chemical Scarification $\left(\mathrm{H}_{2} \mathrm{SO}_{4}\right)$ : the seeds were soaked in a concentrated $\mathrm{H}_{2} \mathrm{SO}_{4}(96 \%)$ for 5, 10 and 15 minutes and then stirred very well then washed by tap water.
Mechanical scarification: sandpaper has been used to scratch of seed hard coat (Transeau, 1994).

Hot water: the seeds were soaked in a hot water with the degree of $\left(75-95 C^{\circ}\right)$ for 5,10 , 15 minutes.

Normal (Tap) water: the seeds were immersed in normal water for 1, 2, and 3 days.

Gibberellic acid $\left(\mathbf{G A}_{3}\right)$ : the celtis seeds were soaked in Gibberellic acid at 500, 1000, 2000 ppm for five minutes in a dark condition with the degree of room temperature.

Fruit: seed with exocarp of the Celtis species used as a treatment to compare with control. 


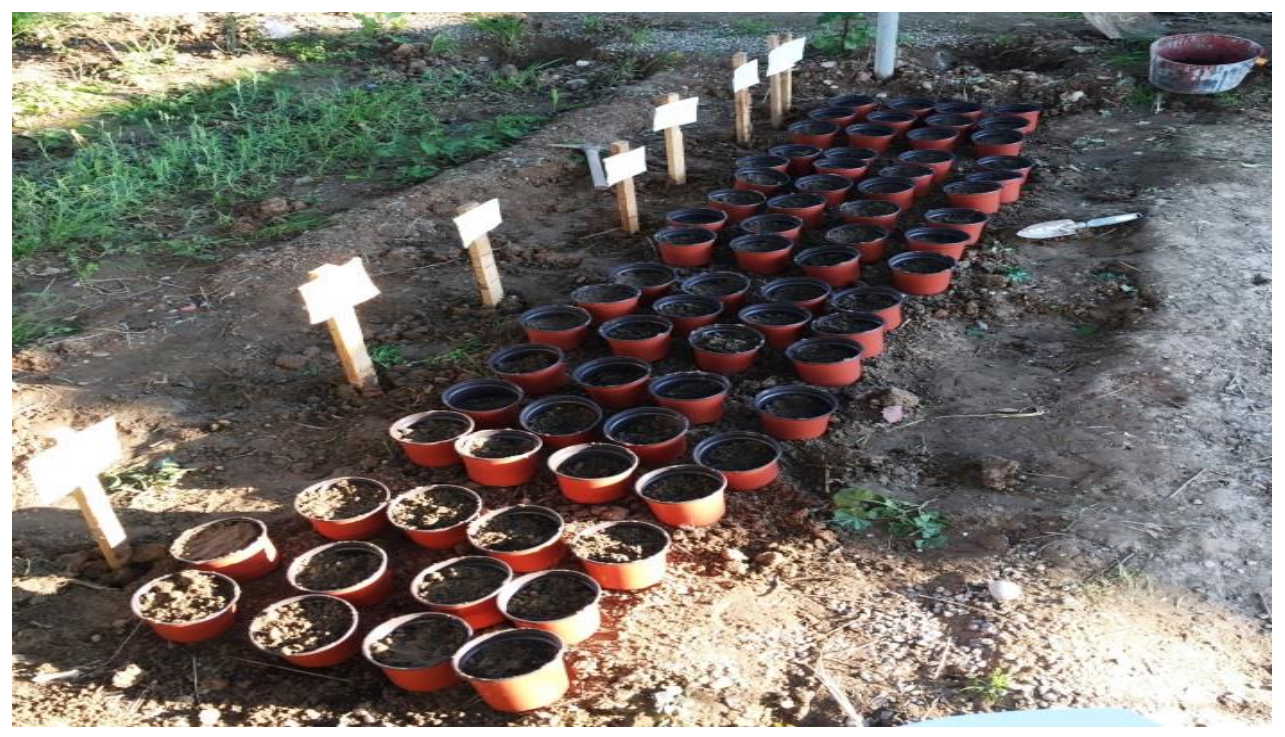

Fig. (2): A complete design of the research after planting tree seeds.

\subsection{Experimental design and Statistical analysis:}

The study carried out at the field of Lemon Tree Trust organization at Domiz1 camp. For each treatment replicated 3 times, each experimental unit seeded with 25 seeds in brown plastic pots with $(24 * 21.8$ height in Diameter) in sandy soil (Figure 2). After all these seeds were treated by these pretreatment then planted in a brown plastic pots with $(24 * 21.8$ height in Diameter) in sandy soil (Figure 2). On the beginning of February 2019, the germinated seeds were weekly counted up to the last of June. When the shoot came out on the ground counted as a seedling emerged. Experimental design where used in this study was completely random design by distribution of 1800 Celtis species seeds on three groups of replications per treatment. For managing seedling emergence and germination of seeds (excel) Microsoft office has been used. While, the data was analyzed by the analysis of variance (ANOVA table). Student-Newman-Keuls test which is two by two test used to show the significant differences between treatments at $(\mathrm{P}<0.05)$ this test belong to R-system program ( $\mathrm{R}$ Development Core Team, 2019).

\section{RESULT AND DISCUSSIO}

The results, as shown in Table 1, indicate that germinate rate responded differently in a significant way depending on the intensity and duration of the treatment. 
Table 1: Analysis of Variance between treatments

\begin{tabular}{llccccc}
\hline Celtis tournefortii & & Df & Sum Sq & Mean Sq & $\begin{array}{c}F \\
\text { value }\end{array}$ & $\operatorname{Pr}(>\mathrm{F})$ \\
\cline { 2 - 6 } & Treatment & 17 & 478.8 & 28.163 & 4.805 & $4,805 e^{-066^{* * *}}$ \\
\hline Residuals & 54 & 316.5 & 5.861 & & \\
\hline
\end{tabular}

\subsection{Germination rate:}

In a comparison among the tested pretreatments, the most noticeable result was belong to the control, where low germination was recorded $(22 \%)$. This low percentage of germination of Celtis species seeds have already reported by many studies due to their hard endocarp of the seeds because endocarp provide physical protection to the seed from herbivorous and disease (Dardick \& Callahan, 2014). By way of illustration, Isfendiyaroglu \& Ozeker (2002) highlighted that it's difficult to obtain good seed germination without pretreatment, moreover, Mahdi et al. (2018) have found around 16\% the seed germinated without treatment. Furthermore, the findings also showed a difference between seed germination percentage of control "without exocarp" (22\%) and fruit "with exocarp" (40\%). These findings were suggested that the exocarp of the drupes facilitates and increases the germination success. High level of nutriment in the exocarp body can lead to promote the germination niche and seedling emergence (Cowan et al., 1997). In addition, there was a significant difference in percentage of seed germination treated by hot water depending the soaking duration $(5,10$ and 15 minutes) with $(29 \%, 25 \%$ and $25 \%)$ respectively. it is clearly obvious that the seed germination percentage decreased at both soaking peroids 10 and 15 minutes which led to embryos death because of the duration of water boil (Salih et al., 2016). There is an improvement in the percentage of seed germination which leads to exchange gases and softens the hard coat (Mohamed-Yaseen et al., 1994). Like hot water treatment, there was an improvement of seed germination percentage soaking in $\mathrm{H}_{2} \mathrm{SO}_{4}$ for 5 minutes (30\%), while the seed germination percentage were reduced with increasing the soaking period from 10 and 15 minutes (15\% and $11 \%$ ) respectively (Figure 3 ). This negative relationship between the germination rate success and the duration of the soaking in $\mathrm{H}_{2} \mathrm{SO}_{4}$ resulting from preventing the gas exchanges (Mohamed-Yaseen et al., 1994).

Furthermore, the effect all of three (Stratification for 3 months, Mechanical scarification, and seed treated with concentration $500 \mathrm{ppm}$ of gibberellic acid in five minutes soaking), were much better than other previous treatments $\left(\mathrm{H}_{2} \mathrm{SO}_{4}\right.$, hot water, etc. $)$. For example, seed stratification for three months, the germination percentage was $46 \%$. This result is in agreement with previous studies tested the seed germination ecology of Celtis spp. e.g. Sheat (1948); Griffiths \& Huxley (1992); Yücedağ \& Gültekin (2008); Guney et al., (2008); Acar and Ercisli, (2017). On the other hand, the stratification for one and two months have increased less effectiveness the seed germination percentage (34\% and 38\% against $46 \%$ under three month stratification) respectively. Moreover, the Mechanical scarification the percentage of seed germination was $(46 \%)$, the finding result was in agreement with the result of Kumar (1990) who highlighted that the mechanical scarification lead to soften the hard coat of seed and increased the seed germination of Celtis species. As well as, seed treated with concentration 500ppm of gibberellic acid increased the seed germination which was (46\%) and this finding was similar to the result of Shant and Rao (1973), Sahai et al. (1977) whom reported that the 500ppm concentration of $\mathrm{GA}_{3}$ five minutes soaking was the best concentration of increasing seed germination of Lathyrus aphaca. Whilst, seed treated with concentration 1000 and 2000ppm of gibberellic acid for five minutes soaking increased the seed germination which were $37 \%$ and $30 \%$ respectively. (Figure 3)

Another important finding of this study was that the results showed decreasing in the seed germination percentage during applying some pre-sowing treatments if it compared to the control of the study which was (22\%). By way of illustration, there was a declining in the rate 
of seed germination after 10 and 15minutes $\mathrm{H}_{2} \mathrm{SO}_{4}(15 \%$ and $11 \%$ ) respectively, it might kill the embryo (Mahdi et al., 2018). Moreover, there was no increasing in the rate of seed germination when it treated with normal water under soaking duration of 1 and 2 days (with $22 \%$ and 20\%, respectively) compared to the control (with $22 \%$ germination rate). The seed germination under hot water soaking for 10 and 15 minutes were $25 \%$ and $25 \%$ respectively. Similar trend was found with the soaking in 10 and 15 minutes Hot water where the seed germination was $22 \%$ and
$20 \%$. Consequently, there is some evidence that the growing environment conditions (Grubb, 1977) can effect on the germination success rate of the seeds (Singh et al., 2004). Furthermore, the characteristics of heritability, nursery conditions where seeds are sown and the parent trees could affect the germination rate of the plant species. However, in spite of all reason that declining the rate of seed percentage, which means not all the treatment will increase the seed germination.

(Figure

$3)$.

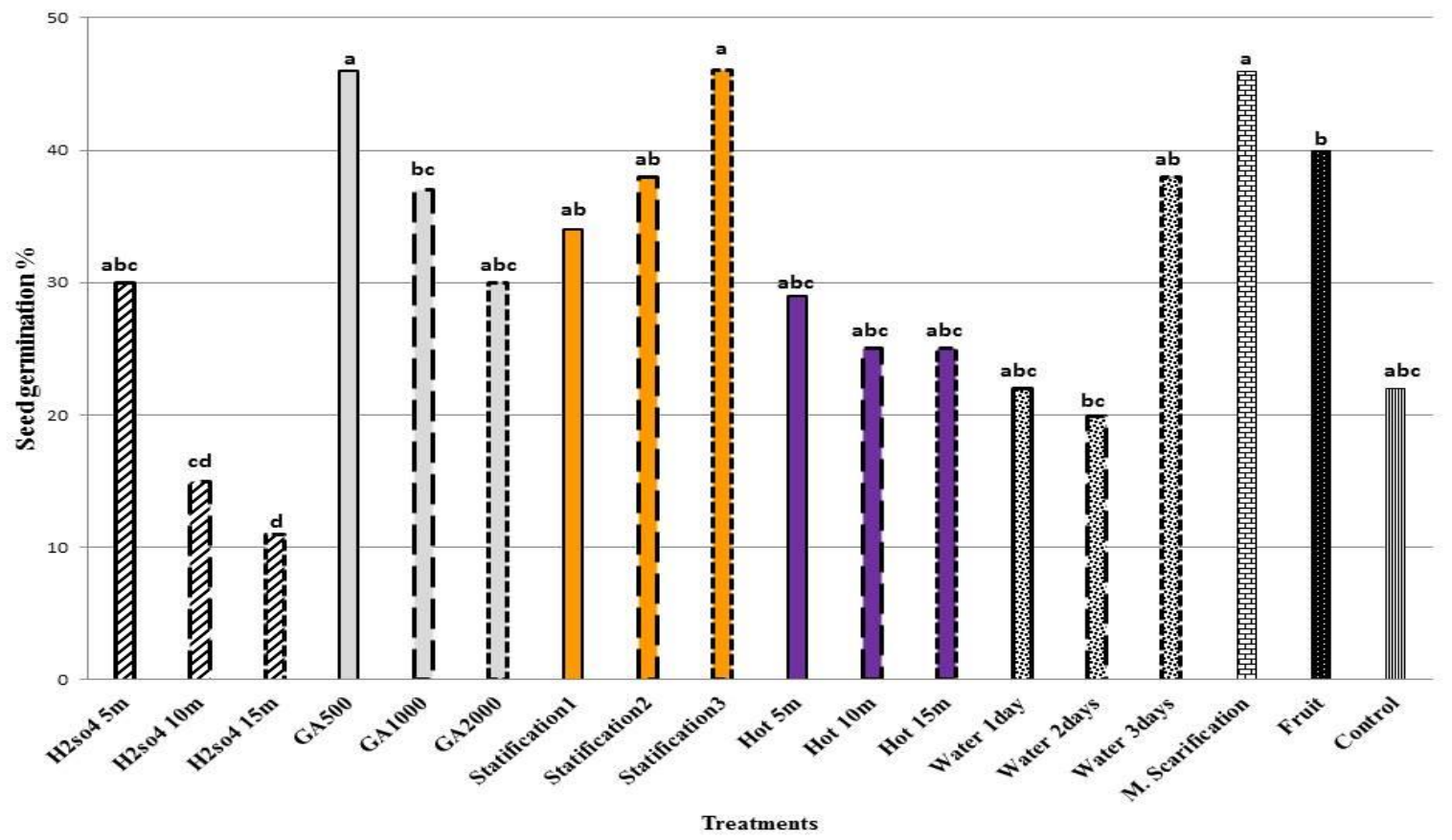

Fig. (3): Seed germination percentages under different pre-sowing treatments 


\section{Seedling emergence timing of the Oriental Hackberry tree species (Celtis tournefortii)}

The sowing timing results are consistent with those previously recommended by Mahdi et al. (2018) when analyzing a global sowing timing for sixteen tree species in Kurdistan Region. Globally, the seed germination of this Oriental Hackberry tree species started from February to March. Surprisingly, the stratification treatment not only increases the germination success rate but also promote an early seedling emergence (started in February). This interesting finding enhances the idea that the stratification is an important treatment factor to break the physical dormancy (Baskin and Baskin 1998). While, seed that often were treated with the other treatments were started on March and achieved the optimum germination rate on April (Figure 4). According to the Piotto and Di Noi (2003) the tree species belong to the Mediterranean and Irano-anatolian region which needs moisture and cold season finish on February and rain continue up to April. For the best seed germination obtain some researcher recommended 90 days of cold Stratification (Sheat, 1948; Griffiths \& Huxley 1992; Yücedağ \& Gültekin, 2008; Guney, et al., 2008; Acar \& Ercisli., 2017). (Figure 4). It is therefore likely that such connections exist between the seedling emergence and environmental condition to maximize the survival of the seedling particularly under harsh environmental condition such as in the IranoAnatolian Region (Cold winter and hot-dry summer). This finding has important implication, particularly for the managers of the plant nurseries, for developing a time table for the suitable sowing time of the tree species seeds. 


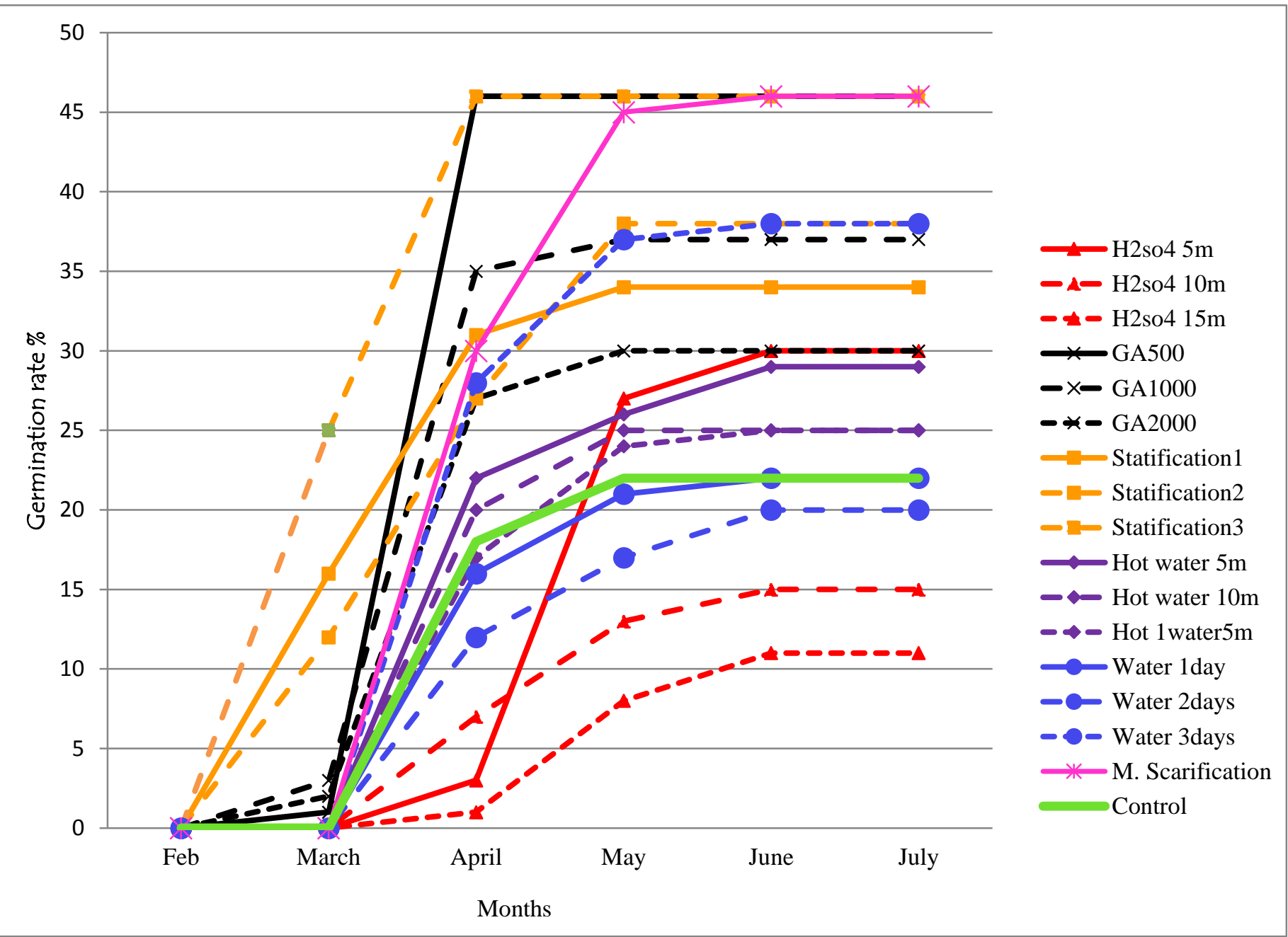

Fig. (4): Celtis tournefortii seed treatments and seedling emergence timing.

\section{CONCLUSION}

For obtaining and producing maximum seed germination, it required the seeds pretreatments. The coat of Celtis species is hard, so it germinates with low percentage and takes long time at the field. The present research of seeds pre-sowing treatments would have a potential effect on the field practically. Among all applied treatments in this study, cold stratification, $\mathrm{GA}_{3}$ with 500ppm concentration and Mechanical scarification had a great positive effect of increasing the percentage of seed germination and the seedling growth of $C$. tourefortii in comparison with other tested treatments. However, not all treatments are good to use to increase the seed germination for $C$. tournefortii such as, Hot Water, $\mathrm{H}_{2} \mathrm{SO}_{4}$ for long time.
Furthermore, the research results showed that the suitable seedling emergence for $C$. tournefortii is on March with all pretreatment that used in this study except stratification which started on February and achieved the optimum germination rate on April.

Acknowledgement: We would like to thanks Lemon Tree Trust organization in Domiz1 camp, Kurdistan Region for giving their field and support our research as well as we would like to thank College of Agriculture/ University of Duhok for their valuable support, finally, we are really grateful to Mr. Shiyar Mohammed for his great proofreading.

\section{REFERENCES}

Acar, I. Yasar, H. And Ercisli, S. (2017). Effects of dormancy-breaking treatments on seed germination and seedling growth of Pistaciakhinjuk Stocks using as rootstock for 
pistachio trees.Journal of Applied Botany and Food Quality, 90: 191-196.

Baskin, C. C., \& Baskin, J. M. (1998). Seeds: ecology, biogeography, and, evolution of dormancy and germination. Elsevier.

Bean, W., \& Clarke, D. L. (1981). Trees and shrubs hardy in Great Britain. Vol: 1-4 and Supplement.

Chevallier, A. (1996). The encyclopedia of medicinal plants. Dorling Kindersly, London. Davis, P.H. 1982. Flora of Turkey and the East Aegean Islands, Vol. 7, Edinburgh.

Cowan, M. R., Gabel, M. L., Jahren, A. H., \&Tieszen, L. L. (1997). Growth and biomineralization of Celtisoccidentalis (Ulmaceae) pericarps. American Midland Naturalist, 266-273.

Dardick, C., \& Callahan, A. M. (2014). Evolution of the fruit endocarp: molecular mechanisms underlying adaptations in seed protection and dispersal strategies. Frontiers in plant science, $5,284$.

Demir, F., Doğan, H., Özcan, M., Hacıseferoğulları, H. (2002). Nutritional and Physical Properties of Hackberry (Celtisaustralis L.). Journal of Food Engineering, 54 (3): 241-247.

Dirr, M. A. H. (2012). The reference manual of woody plant propagation, from seed to tissue culture, Michael A. Dirr, Charles W. Heuser.

Dirr, M. A., \& Heuser, C. W. (1987). The reference manual of woody plant propagation: from seed to tissue culture: a practical working guide to the propagation of over 1100 species, varieties, and cultivars (Vol. 239). Athens: Varsity Press.

Doygun, H., Ok, T. (2006). Kahramanmaraş Kenti Açık- Yeşil Alanlarında Ağaçlandırma Çalışmalarının Değerlendirilmesive Öneriler. KSÜ Fen ve Mühendislik Derg., 9(2): 94-103.

Ellis, R. H., Hong, T. D., \& Roberts, E. H. (1985). Handbook of seed technology for genebanks. v. 2: Compendium of specific germination information and test recommendations. Handbooks for Genebanks (IBPGR). 405.
Griffiths, M., \& Huxley, A. (Eds.). (1992). The new Royal Horticultural Society dictionary of gardening. Macmillan.

Grubb, P. J. (1977). The maintenance of species richness in plant communities: the importance of the regeneration niche. Biological reviews, 52(1), 107-145.

Gültekin, H.C. 2007. Yabanıl Meyveli Ağaç Türlerimizve Fidan Üretim Teknikleri. T.C. Çevreve Orman Bak., AGM, Fidanlıkve Tohumİşleri Daire Başkanlığı, Ankara, 52 s.

Guney, D., Turna, İ., \& Atar, F. (2008). The effects of different pretreatments on germination of Mediterranean hackberry (Celtis australis L.) seeds.)

Isfendiyaroglu, M. \& Özeker, E. (2002). The relation between phenolic compounds and seed dormancy in Pistacia spp. In Ak B.E. (ed.). 11 GremaSerr pistachios and almonds. Chieres Options Mediterraneennes. (56). 227-232.

Judd, W.S., Sander, R.W \& Donoghue, M.J. (1994). Angiosperm family Pairs: Preliminary Cladistic Analyses. Harvard Papers in Botany 5: $1-51$.

Kayacık, H. (1981). Ormanve Park Ağaçlarının Özel SistematiğiII. Cilt (Angiospermae). İ.Ü. Orman Fak. Yayın No: 287, İstanbul.

Kumar, D. (1990). Maturity indices and pretreatment studies on the seeds of Celtis australis Linn (Doctoral dissertation, M. Sc. Thesis, Dr. YS Parmar University of Horticulture and Forestry, Solan, India. 87p).

Mahdi, H. S., Hussein, W. I., Salih, H. M., \& Youssef, S. M. A. A. (2018). Effect of presowing treatments on seed germination of $\mathrm{P}$ eurycarpa and P. khinjuk - Kurdistan region. Journal of Duhok University, 20(1), 105-113.

Mahdi, H. S., Yaseen, D. F., Hassan, H. N., SelahAlden, M. T., Mahmood, M. J., Hameed, N. A., ... \& Youssef, S. M. A. A. (2018). Seed germination ecology and seedling emergence of sixteen tree species autumn sown. Journal of Duhok University, 20(1), 50-63.

Mohamed-Yaseen, Y., S.A. Barringer, W.E. Splittstoesser and S. Costanza (1994). The role of seed coats in seed viability. The Botanical Review, 60: 426-439. 
Piotto, B., \& Di Noi, A. (2003). Seed propagation of Mediterranean trees and shrubs.

Sahai, R., Kaur, G., \& Roy, P. S. (1977). Effect of some growth regulators and chemicals on seed germination and early seedling growth of Lathyrus aphaca Linn.[India]. Indian Journal of Ecology.

Salih, T.W.,Nazar,M. S., Gailan, B. A., and Hameed, A. R. (2016). Effect of soaking periods in sulfuric acid and sowing media on germination of RhuscoriariaL. seeds under field conditions. Journal of University of Duhok, (19)1: 288294

Sattarian, A. (2006). Contribution to the biosystematics of Celtis L.(Celtidaceae) with special emphasis on the African species.

Shahbaz, S. E. (2010). Trees and Shrubs, A field guide to the trees and shrubs of Kurdistan region of Iraq.

Shant P.S. and S.N. Rao.(1973). Note on the effect of gibberellic acid on seed germination and seedling growth of acidlime (Citrus aurantifolia). Progressive Hort. 5(3):63-65.

Sheat, W. G. (1948). Propagation of trees, shrubs and conifers. Propagation of trees, shrubs and conifers.

Singh, B., Bhatt, B.P., Prasad, P. (2004). Effect of seed source and temperature on seed germination of Celtisaustralis L.: a promising agroforestry tree-crop of Central Himalaya, India. Forests, Trees and Livelihoods, 14 (1): 53-60

Song, B.H., Wang, X.-Q., Li, F.-Z.\& Hong, D.-Y. (2002). Further evidence for ParaphylyCeltidaceae from the chloroplast gen matK. Plant Systematics \& Evolution 228:107-115.

Tardío, J., Pardo-de-Santayana, M., Morales, R. (2006). Ethnobotanical review of wild edible plants in Spain. Botanical Journal of the Linnean Society, 152, 27-71.

Todzia, C.A. (1989). A Revision of Ampelocera (Ulmaceae). Annals of the Missouri Botanical Garden 76: 1087-1102.
Townsend C. C. (1980). Ulmaceae in: Townsend C.C. \& E.Guest; Flora of Iraq, Volume 4 Part one: Cornaceae to Rubiaceae.-Ministry of Agriculture and Agrarian Reform, Iraq: 486499.

Transeau, E. N. (1994). General botany. Discovery Publishing House.

Ulloa, C. \&Jørgensen, P.M., (1995). Arboles y arbustos de los Andes del Ecuador, 2 ndedition.Abya-Yala, Quito.

Yıldırım, I., Uğur, Y., \& Kutlu, T. (2017). Investigation of Antioxidant Activity and Phytochemical Compositions of CeltisTournefortii. Free Radicals \& Antioxidants, 7(2).

Youssef, S., Mahmood, A., Cartereau, M., \& Vela, E. (2018).New cytological, morphological, and chorological data on Prospero seisumsianum (Ruk? ans\&Zetterl.)Yıldırım (Asparagaceae) from the Zagros area. Turkish Journal of Botany, 42(5), 581-590.

Youssef, S., Mahmood, A., Mahdi, H., and Vela, E., (2015). New contribution on Orchids (Orchidaceae) of Duhok Province in Kurdistan Region (N-Iraq). Journal Europäischer Orchideen, 47, pp. 405-420.

Youssef, S., Mahmoud, A. M., \& Vela, E. (2017). On the genus Sternbergia (Amaryllidaceae) in Iraq. In Anales del Jardin Botanico de Madrid (Vol. 74, No. 1, p. 7). Real Jardín Botánico.

Youssef, S.,Galalaey, A., Mahmood, A., Mahdi, H., \&Véla, E. (2019). Wild orchids of the Kurdistan Region areas: a scientific window on the unexpected nature of the North-Western Zagros. La Motte-d'Aigues (FR): Société Méditerrannéenned' Orchidologie, $164 \mathrm{P}$. ISBN: 978-2-900082-08-9.

Yücedağ, C., \& Gültekin, H. C. (2008). Adi Çitlenbik (Celtis australis L.) veDoğuÇitlenbiği (Celtis tournefortii Lam.). Süleyman Demirel Üniversitesi Fen Bilimleri Enstitüsü Dergisi, 12(3), 


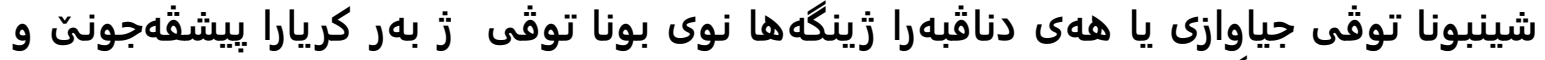

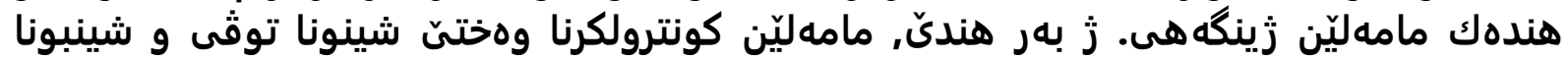

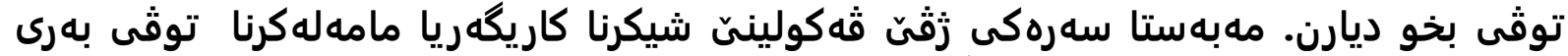

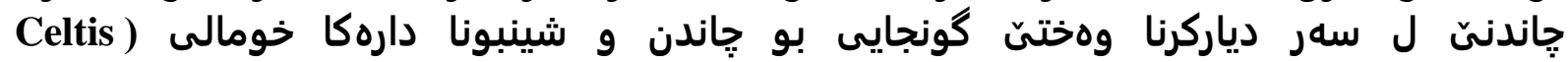

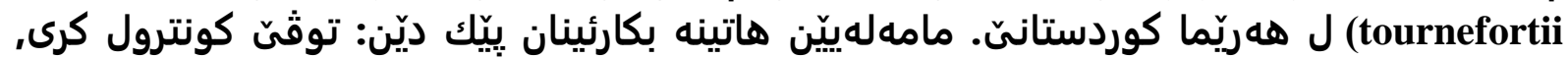

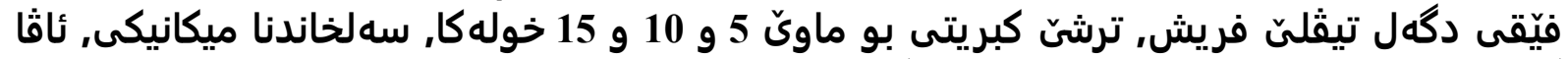

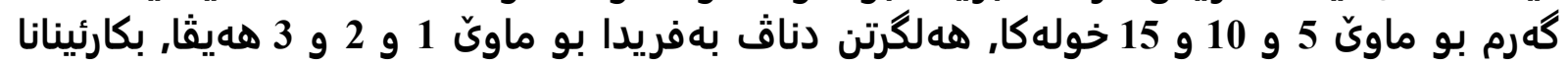

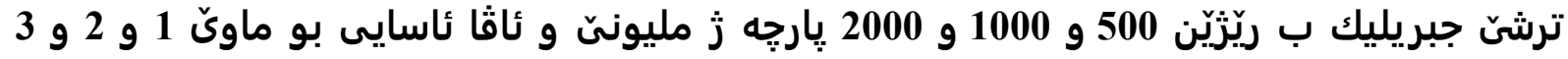

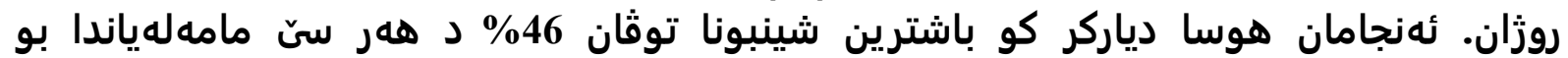

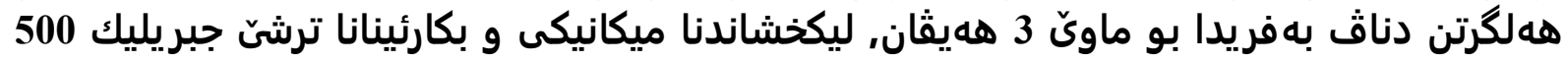

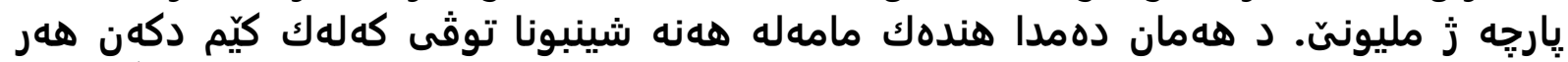

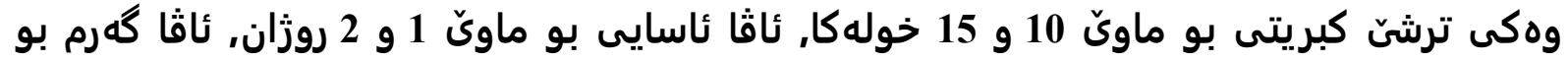

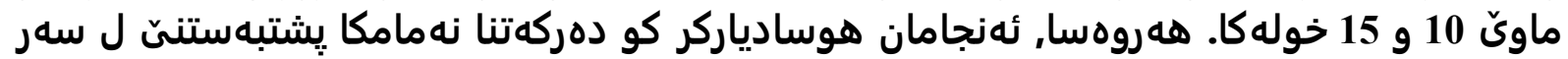

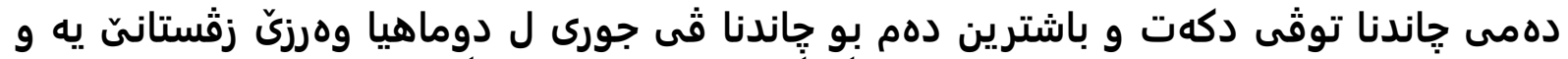

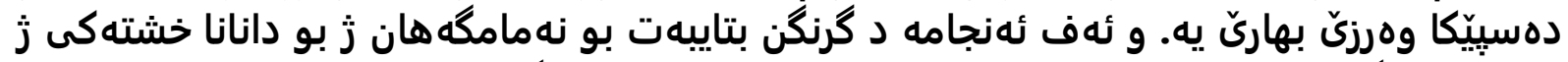

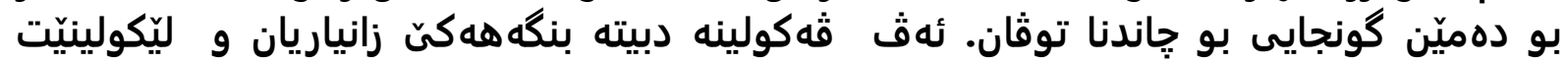

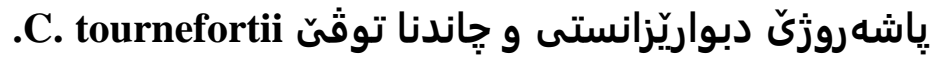

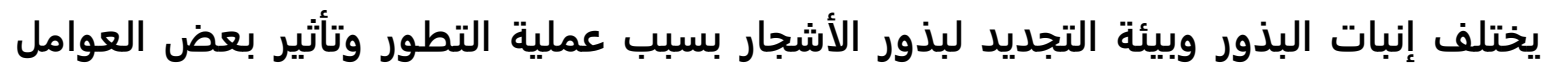

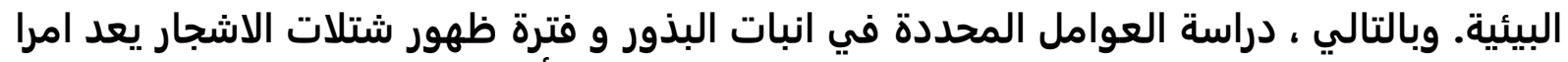

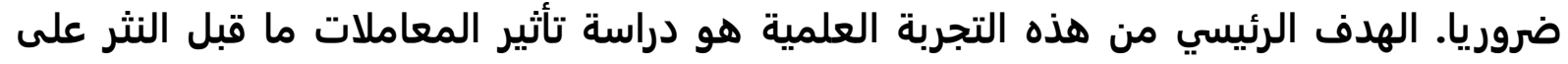

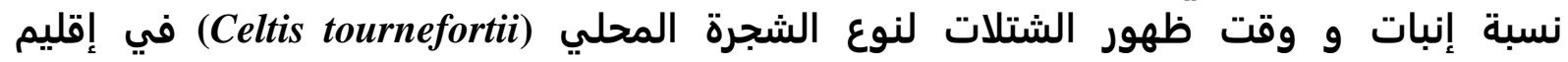

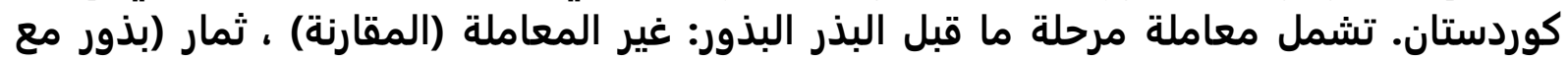

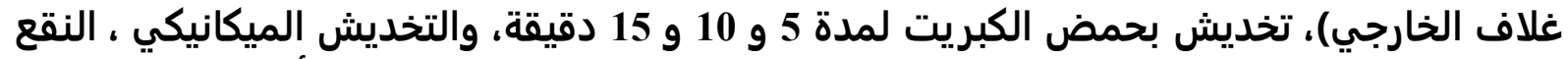

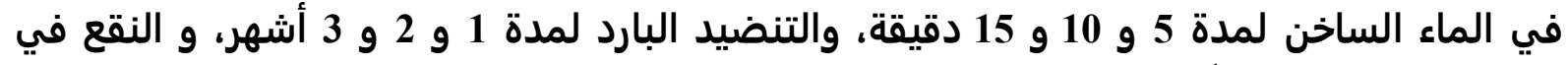
حمض الجبريليك بتراكيز 500 ، 1000 و 15000 دفقة والني في المليون، والنقع في الماء لمدة 1000 ، 2 و 3 
أيام. وأظهرت النتائج أن معدل إنبات البذور 46٪ حيث تم الحصول عليها في المعاملات التالية

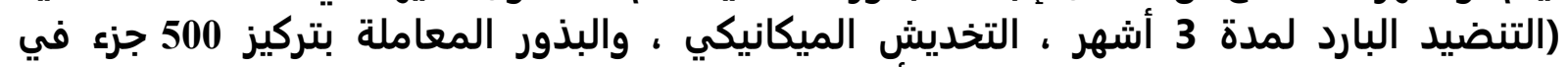

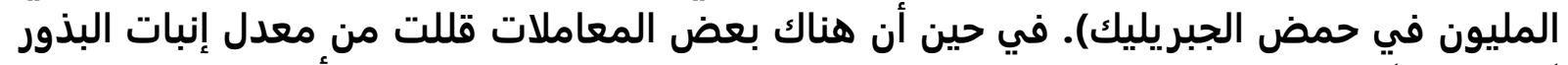

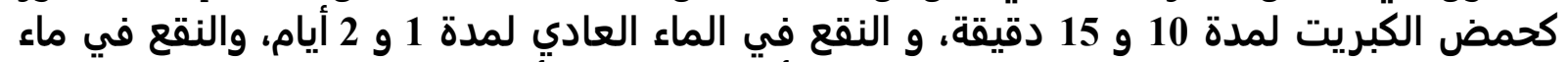

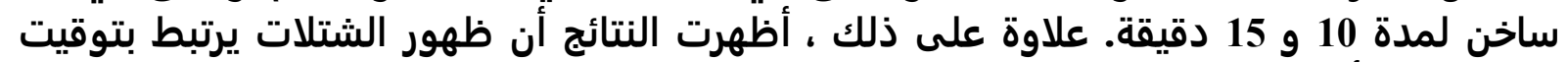

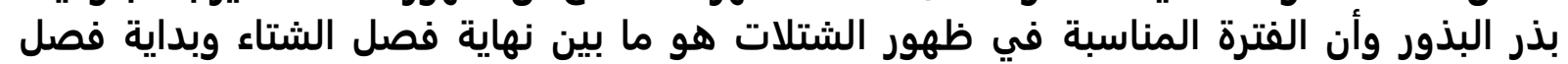

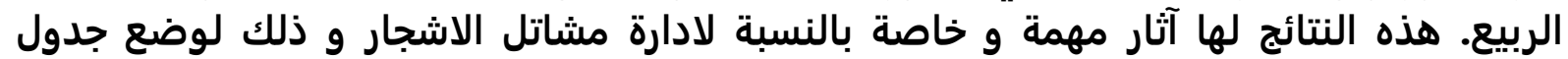

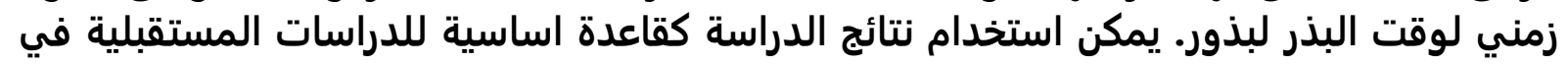
إنبات البذور Celtis tournefortii و زيادة معدل البذر نتائ نجاح الإنبات. 